\title{
Improving nitrogen and irrigation water use efficiency through adaptive management: A case study using annual ryegrass
}

\author{
Melake K. Fessehazion $^{\mathrm{a}, *}$, Richard J. Stirzaker ${ }^{\mathrm{a}, \mathrm{b}}$, John G. Annandale ${ }^{\mathrm{a}}$, Colin S. Everson ${ }^{\mathrm{a}, \mathrm{c}}$ \\ a Department of Plant Production and Soil Science, University of Pretoria, Private Bag X20, Hatfield 0028, Pretoria, South Africa \\ ${ }^{\mathrm{b}}$ CSIRO Sustainable Agricultural National Research Flagship and Cooperative Research Centre for Irrigation Futures, Australia \\ c School of Bioresources Engineering and Environmental Hydrology, University of KwaZulu-Natal, Private Bag X01, Scottsville, Pietermaritzburg 3209, South Africa
}

\section{A R T I C L E I N F O}

\section{Article history:}

Received 26 October 2010

Received in revised form 14 March 2011

Accepted 29 March 2011

Available online xxx

\section{Keywords:}

Forage yield

Soil solution nitrate

Threshold soil nitrate

Wetting front detector

\begin{abstract}
A B S T R A C T
Nitrogen is often poorly managed in irrigated agro-ecosystems. Accumulation and leaching of $\mathrm{N}$ can occur due to excessive fertiliser $\mathrm{N}$, high soil inorganic $\mathrm{N}$ carryover between seasons, rapid mineralisation in spring and poor irrigation scheduling. This can reduce forage yield, quality and $\mathrm{N}$-use efficiency, and lead to pollution of soil and water resources. Experiments were conducted to test whether adaptive nitrogen and irrigation management approaches using ryegrass as a case study could (1) reduce $\mathrm{N}$ application without compromising yield, (2) maintain or improve forage quality, (3) improve water use efficiency, and (4) minimise potential for nitrate leaching, using the current local recommended fertiliser rates as a baseline. Adaptive management strategies based on the concentration of nitrate measured in a wetting front detector at different depths reduced fertiliser $\mathrm{N}$ application by $28-32 \%$ compared to the baseline recommendation, reduced residual soil $\mathrm{N}$ that is potentially leachable, and improved forage quality without reduction in forage yield. The essence of the adaptive approach is to set thresholds for action that are relatively easy to monitor, based on a simple conceptualisation of the system. The thresholds were defined for the depth that a strong wetting front could be passively detected under field conditions, and for the concentration of nitrate in the percolating water. These thresholds were chosen as simple integral measures of the water and $\mathrm{N}$ cycles. Results suggest that a good adaptive manager would improve the thresholds for action as more experience is gained.
\end{abstract}

(ㄷ) 2011 Elsevier B.V. All rights reserved.

\section{Introduction}

Global use of nitrogen $(\mathrm{N})$ fertiliser has increased more than seven-fold since the 1960s (Smil, 1999; Tilman et al., 2002). Only half of this nitrogen is recovered in harvested crops, with the remainder entering aquatic and atmospheric systems, contributing to one of the main human-induced perturbations to the earth's environment (Smil, 1999; Steffen et al., 2007). Despite decades of research on matching fertiliser applications to crop requirements, agriculture remains a major source of environmental contamination (Isermann, 1990; Tamminga, 1992; Matson et al., 1997; Stirzaker, 1999; Goulding, 2000).

Irrigated pasture for milk production is an example of a high $\mathrm{N}$-use agricultural system. Growth and quality are very responsive to applications of nitrogen fertiliser and since $\mathrm{N}$ is seen as a low cost input for the dairy industry (Tas et al., 2006), excessive applications are common (Eckard et al., 1995). However, high levels of

\footnotetext{
* Corresponding author. Tel.: +27 12420 5277; fax: +27 124204120 .

E-mail address: melake@tuks.co.za (M.K. Fessehazion).
}

$\mathrm{N}$ can reduce pasture quality through toxic levels of nitrate, excessive protein content, increased non-protein nitrogen and reduced metabolisable energy (Peyraud and Astigarraga, 1998).

Past research has provided a fairly robust management guideline for famers, such as applying $50 \mathrm{~kg} \mathrm{Nha}^{-1}$ per growth cycle (Eckard et al., 1995). Such rigid guidelines could be improved by (1) soil $\mathrm{N}$ testing to estimate $\mathrm{N}$ mineralisation and $\mathrm{N}$ carryover between harvests (Andraski and Bundy, 2002; Collins and Allinson, 2004; Miles, 2007), (2) mass balance accounting to match inputs and outputs (Hatfield and Prueger, 2004), and (3) improving irrigation practices (Samanasena et al., 2004). However, taking the appropriate measurements, for example by soil coring, would be expensive and time consuming for each harvest (Collins and Allinson, 2004), particularly as nitrate levels can change rapidly during the growing season after rain or irrigation.

Adaptive management (Walters, 1986) is an approach that sits between a guideline, on the one hand, and trying to measure or estimate all components of the system, on the other (like using an $\mathrm{N}$ mass balance approach where components such as leaching, volatilisation and denitrification are difficult to measure or estimate). Adaptive management is generally considered to be the best 
Table 1

Monthly mean minimum and maximum temperature, and total precipitation recorded during the 2007 and 2008 growing seasons, Cedara, South Africa.

\begin{tabular}{|c|c|c|c|c|c|c|c|c|c|c|}
\hline Year & Parameter & March & April & May & June & July & August & September & October & November \\
\hline \multirow[t]{3}{*}{2007} & $T_{\min }\left({ }^{\circ} \mathrm{C}\right)$ & 25.1 & 23.6 & 23.3 & 19.6 & 20.5 & 22.0 & 23.8 & 21.3 & 23.1 \\
\hline & $T_{\max }\left({ }^{\circ} \mathrm{C}\right)$ & 13.7 & 10.9 & 4.3 & 1.8 & 1.3 & 3.7 & 10.4 & 11.2 & 12.3 \\
\hline & Rain (mm) & 68.2 & 34.7 & 10.0 & 32.6 & 0 & 14.2 & 17.5 & 155.5 & 77.4 \\
\hline \multirow[t]{3}{*}{2008} & $T_{\min }\left({ }^{\circ} \mathrm{C}\right)$ & 24.7 & 22.2 & 23.2 & 19.4 & 21.1 & 22.9 & 22.8 & 22.3 & 23.7 \\
\hline & $T_{\max }\left({ }^{\circ} \mathrm{C}\right)$ & 13.2 & 9.0 & 7.4 & 4.2 & 2.9 & 5.9 & 5.9 & 12.9 & 13.3 \\
\hline & Rain (mm) & 3.0 & 71.3 & 8.2 & 21.9 & 13.0 & 5.4 & 42.6 & 37.5 & 82.2 \\
\hline
\end{tabular}

$T_{\min }$ is mean monthly minimum temperature; $T_{\max }$ is mean monthly maximum temperature.

Table 2

Selected soil physical and chemical properties of the experimental site.

\begin{tabular}{|c|c|c|c|c|c|c|}
\hline Physical $^{a}$ & $0-0.2 \mathrm{~m}$ & $0.2-0.4 \mathrm{~m}$ & $0.4-1.0 \mathrm{~m}$ & Chemical $^{\mathrm{c}}$ & 2007 & 2008 \\
\hline Clay (\%) & $34.3(2.9)^{\mathrm{b}}$ & $37.4(5.8)$ & $45.0(3.5)$ & Total N (\%) & $0.32(0.02)$ & $0.29(0.03)$ \\
\hline Silt (\%) & $33.9(3.0)$ & $33.5(2.5)$ & $25.8(1.2)$ & Organic C (\%) & $2.8(0.21)$ & $3.2(0.16)$ \\
\hline Sand (\%) & $31.8(1.6)$ & $29.1(6.4)$ & $29.2(2.8)$ & $\mathrm{pH}(\mathrm{KCl})$ & $4.6(0.11)$ & $4.4(0.17)$ \\
\hline Saturation $\left(\mathrm{m}^{3} \mathrm{~m}^{-3}\right)$ & $0.498(0.009)$ & $0.481(0.032)$ & $0.498(0.019)$ & $\mathrm{P}\left(\mathrm{mg} \mathrm{kg}^{-1}\right)$ & $28(8)$ & $24(5)$ \\
\hline Field capacity $\left(\mathrm{m}^{3} \mathrm{~m}^{-3}\right)$ & $0.337(0.014)$ & $0.331(0.005)$ & $0.329(0.046)$ & $\mathrm{K}\left(\mathrm{mg} \mathrm{kg}^{-1}\right)$ & $173(21)$ & $208(23)$ \\
\hline Wilting point $\left(\mathrm{m}^{3} \mathrm{~m}^{-3}\right)$ & $0.206(0.012)$ & $0.212(0.016)$ & $0.192(0.018)$ & $\mathrm{Ca}\left(\mathrm{mg} \mathrm{kg}^{-1}\right)$ & $712(29)$ & $820(17)$ \\
\hline Bulk density $\left(\mathrm{kg} \mathrm{m}^{-3}\right)$ & $1220(27)$ & $1280(24)$ & $1170(46)$ & $\mathrm{Mg}\left(\mathrm{mg} \mathrm{kg}^{-1}\right)$ & $156(12)$ & $202(14)$ \\
\hline
\end{tabular}

a Soil physical properties were determined in 2007 prior to planting.

b Standard deviations.

c Soil chemical analysis was conducted in both years prior to planting. Ammonium acetate was used for K, Ca and Mg extraction. Organic carbon and nitrogen were estimated by mid-infrared spectroscopy. P measured with Bray I.

approach for managing systems with high uncertainty, or where it is impossible or impractical to collect all the necessary information (Holling, 1978; Walters, 1986; Lee, 1993). Although usually used for addressing complex socio-ecological problems, adaptive management may also be a sensible strategy for the seemingly relatively straight forward problem of optimising $\mathrm{N}$ nutrition and crop water supply.

Successful adaptive management hinges on our ability to identify a threshold which is easy to measure and that can be linked to action and on-going learning (Stirzaker et al., 2010). Since monitoring is expensive, we seek a measurement that can integrate many of the processes involved in the soil water balance and $\mathrm{N}$ cycle, in this case the use of a wetting front detector (WFD) which is a passive lysimeter that approximates the water and nitrate moving past a certain depth in the soil profile (Stirzaker, 2003; van der Laan et al., 2010). The objectives of this paper are to test the hypotheses that adaptive $\mathrm{N}$ and water management approaches can (1) reduce the recommended $\mathrm{N}$ application without compromising yield, (2) maintain or improve forage quality, (3) improve water use efficiency, and (4) minimise potential for nitrate leaching.

\section{Materials and methods}

\subsection{Site description and general crop management}

The experiment was conducted at the Cedara Agricultural Research Council experimental site located in the midlands of KwaZulu-Natal, one of the main milk producing areas of South
Africa (altitude $1076 \mathrm{~m}$ above sea level, $29^{\circ} 32^{\prime} \mathrm{S} ; 30^{\circ} 17^{\prime} \mathrm{E}$ ). The site has a summer dominated mean annual rainfall of $876 \mathrm{~mm}$ and reference evapotranspiration of $1511 \mathrm{~mm}$. Monthly mean minimum and maximum temperatures, and monthly total precipitation recorded from a weather station during the study period are shown in Table 1.

Prior to the commencement of the trial in 2007, replicate undisturbed soil core samples were collected to a depth of $1 \mathrm{~m}$ for determination of basic soil physical properties (Table 2). The site has a deep, red, kaolinitic Hutton soil (Soil Classification Working Group, 1991) with a clay loam texture to a depth of $0.4 \mathrm{~m}$, with a heavier clay soil from 0.4 to $1.0 \mathrm{~m}$. In both years, the fertility status of the soil was determined (Table 2) prior to planting. $20 \mathrm{~kg} \mathrm{Pha}^{-1}$ (super phosphate) was incorporated at planting. Both $\mathrm{N}$ (limestone ammonium nitrate) and $\mathrm{K}$ (potassium chloride) top dressings were applied within two days of each cutting. The seasonal recommended $\mathrm{K}\left(200 \mathrm{~kg} \mathrm{Kha}^{-1}\right)$ was divided by the expected number of growth cycles, while the $\mathrm{N}$ regime was determined by the treatment. Italian ryegrass (Lolium multiflorum) cultivar 'Agriton' was planted on the 6th March in 2007 and 25th March 2008 at a seeding rate of $30 \mathrm{~kg} \mathrm{ha}^{-1}$ and a Cambridge Roller was used to facilitate good contact between the seed and soil. Recommended planting dates for this region is between mid-February and mid-April each year.

A dragline sprinkler irrigation system with a delivery rate of $4.0 \mathrm{~mm} \mathrm{~h}^{-1}$ and a sprinkler spacing of $12 \mathrm{~m}$ was used. Plots were $12 \mathrm{~m}$ wide and $36 \mathrm{~m}$ long with a border spacing between plots of $12 \mathrm{~m}$. Each plot had its own sprinkler lines and was irrigated

Table 3

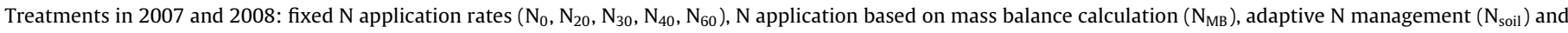
adaptive water management $\left(\mathrm{N}_{\text {water }}\right)$.

\begin{tabular}{|c|c|c|c|c|c|c|c|c|c|}
\hline \multicolumn{4}{|c|}{ Fixed rates } & \multicolumn{2}{|c|}{$\mathrm{N}_{\mathrm{MB}}(2008)$} & \multicolumn{2}{|c|}{$\mathrm{N}_{\text {soil }}(2008)$} & \multicolumn{2}{|c|}{$\mathrm{N}_{\text {water }}(2008)$} \\
\hline 2007 & N rate ${ }^{a}$ & 2008 & $\mathrm{~N}$ rate & Soil $\mathrm{NO}_{3}{ }^{\mathrm{b}}$ & $\mathrm{N}$ rate & Soil $\mathrm{NO}_{3}$ & $\mathrm{~N}$ rate & Soil $\mathrm{NO}_{3}$ & Next irrigation \\
\hline & & $\mathrm{N}_{0}$ & 0 & As initial $\mathrm{N}$ in mass & Eq. (1) & $>50$ & 0 & $\mathrm{WFD}_{30}>25$ & Reduced \\
\hline $\mathrm{N}_{0}$ & 0 & $\mathrm{~N}_{20}$ & 20 & balance calculation & & $25-50$ & 25 & $\mathrm{WFD}_{45}>25$ & Cancelled \\
\hline $\mathrm{N}_{30}$ & 30 & $\mathrm{~N}_{40}$ & 40 & & & $<25$ & 50 & & \\
\hline $\mathrm{N}_{60}$ & 60 & $\mathrm{~N}_{60}$ & 60 & & & & & & \\
\hline
\end{tabular}

a $\mathrm{N}$ rates in $\mathrm{kg} \mathrm{ha}^{-1}$ cycle $^{-1}$.

b Soil solution nitrate in $\mathrm{mg} \mathrm{L}^{-1}$ 


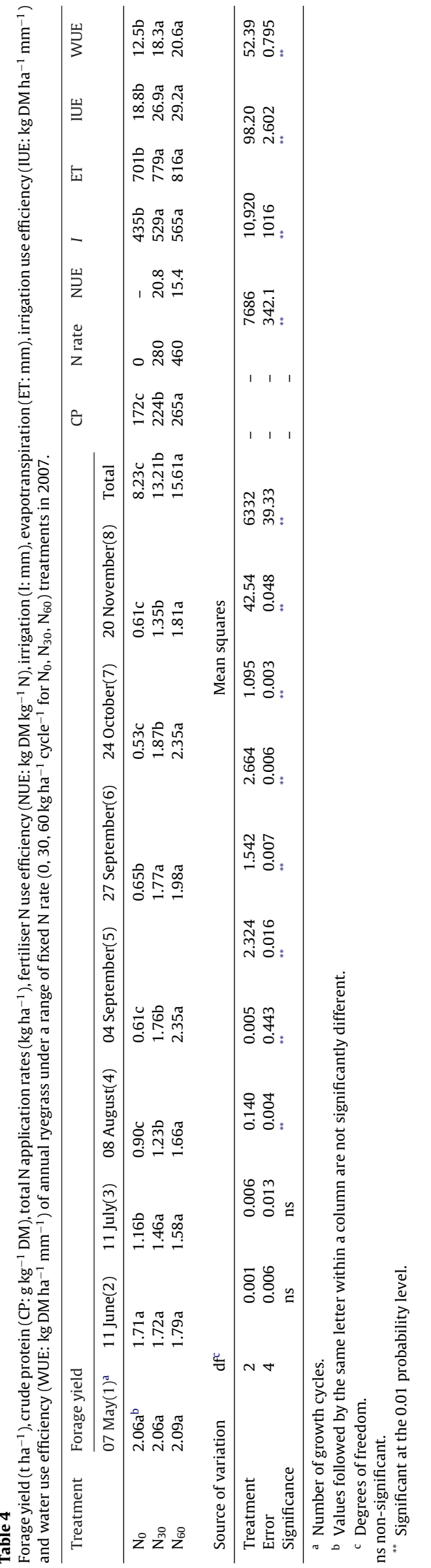

independently by determining the deficit to field capacity using the Diviner-2000 capacitance probe to a depth of $0.6 \mathrm{~m}$ (Sentek ${ }^{\circledR}$, Australia). Plots were irrigated once a week during autumn, spring and summer; and once every two weeks in winter. Treatments were refilled to field capacity except in summer (where about $15 \mathrm{~mm}$ soil deficit was left for rain) and on occasion for the adaptive water management treatment included in this study in 2008 (where irrigation was based on nitrate levels).

A wetting front detector (WFD) is a funnel-shaped, passive lysimeter, used for managing irrigation, salinity and nutrition (Stirzaker and Hutchinson, 2005; Tesfamariam et al., 2009; van der Laan et al., 2010). When the soil around the WFD approaches $3 \mathrm{kPa}$ suction during or shortly after irrigation or rainfall, free water is produced at the base of the funnel (Stirzaker, 2008). The water passes through a filter, is collected in a reservoir, and activates a magnetically latched float. A water sample can later be retrieved for analysis using a syringe. The root zone was determined through soil core sampling to a depth of $1 \mathrm{~m}$, with the majority of roots found in the top $0.6 \mathrm{~m}$. Therefore, WFDs were installed by augering a hole to depths of $0.15,0.30,0.45$ and $0.60 \mathrm{~m}$ in each plot for monitoring depth of wetting and soil solution $\mathrm{N}$ concentration.

\subsection{Treatments}

Three treatments in 2007 and seven treatments in 2008 were set up in a randomised block design with three replications. In 2007, the experiment included three fixed $\mathrm{N}$ rate applications over eight harvests; representing high $\left(\mathrm{N}_{60}: 60 \mathrm{~kg} \mathrm{Nha}^{-1}\right)$, and medium $\left(\mathrm{N}_{30}\right.$ : $30 \mathrm{~kg} \mathrm{~N} \mathrm{ha}^{-1}$ ) forage target yields and a control with zero $\mathrm{N}\left(\mathrm{N}_{0}\right)$. To avoid differential carry-over effects from 2007 affecting the treatments in 2008, the second year trial was carried out on different plots. The experiment was changed in 2008 because in the first two to three growth cycles of 2007, forage yields between $\mathrm{N}$ treatments were similar. In addition there were also high soil solution nitrate levels in the high $\mathrm{N}$ application rate treatment $\left(\mathrm{N}_{60}\right)$, which could be a source of potential leaching. Therefore, in 2008, treatments were improved by estimating/measuring components of the $\mathrm{N}$ balance (such as soil $\mathrm{N}$, mineralisation and crop $\mathrm{N}$ uptake) or by using a simpler method (adaptive management). The data collected in 2007 were used to derive the management thresholds for the adaptive $\mathrm{N}$ and water treatments for 2008. In 2008, treatments included four fixed $\mathrm{N}$ rates and one treatment based on $\mathrm{N}$ mass balance calculations. In 2008, there were also two adaptive treatments, the first reducing $\mathrm{N}$ input and the second reducing irrigation input, both based on nitrate measurements from WFDs. A detailed description of the 2008 treatments follows.

\subsubsection{Fixed $N$ application rates}

No $\mathrm{N}$ was applied at planting to take advantage of high levels of residual $\mathrm{N}$, but $\mathrm{N}$ rates of $0,20,40$ and $60 \mathrm{~kg} \mathrm{Nha}^{-1}\left(\mathrm{~N}_{0}, \mathrm{~N}_{20}, \mathrm{~N}_{40}\right.$ and $\mathrm{N}_{60}$ ) were applied after each harvest. The aim of this series of treatments was to provide the response curve for $\mathrm{N}$.

\subsection{2. $N$ mass balance $\left(N_{M B}\right)$}

This treatment represents the strategy of measuring components of the $\mathrm{N}$ cycle to get $\mathrm{N}$ applications as accurate as possible. $\mathrm{N}$ application was estimated from target crop $\mathrm{N}$ uptake and adjusted downwards to account for initial soil nitrate and estimated mineralisable $\mathrm{N}$, hence simplifying the $\mathrm{N}$ mass balance (Asadi et al., 2002) equation to:

$\mathrm{N}_{\text {fer }}=\mathrm{N}_{\text {up }}-\mathrm{N}_{\text {init }}-\mathrm{N}_{\text {min }}$

where $\mathrm{N}_{\text {fer }}$ is $\mathrm{N}$ input from fertiliser; $\mathrm{N}_{\mathrm{up}}$ is above ground crop $\mathrm{N}$ uptake; $\mathrm{N}_{\text {init }}$ is initial soil inorganic $\mathrm{N}$ and $\mathrm{N}_{\text {min }}$ is predicted mineralisable $\mathrm{N}$. The mass balance approach used here assumes atmospheric $\mathrm{N}$ inputs and gaseous $\mathrm{N}$ losses through denitrification 
Table 5

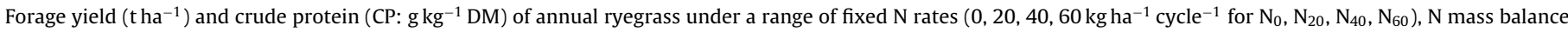
$\left(\mathrm{N}_{\mathrm{MB}}\right)$, and adaptive $\mathrm{N}\left(\mathrm{N}_{\text {soil }}\right)$ and water $\left(\mathrm{N}_{\text {water }}\right)$ treatments in 2008 .

\begin{tabular}{|c|c|c|c|c|c|c|c|c|c|c|c|}
\hline \multirow[t]{2}{*}{ Treatment } & \multicolumn{10}{|c|}{ Yield ( $\left.\mathrm{t} \mathrm{ha} \mathrm{a}^{-1}\right)$} & \multirow[t]{2}{*}{$\mathrm{CP}$} \\
\hline & $\begin{array}{l}28 \text { May } \\
(1)^{a}\end{array}$ & & $\begin{array}{l}01 \text { July } \\
(2)\end{array}$ & $\begin{array}{l}07 \text { August } \\
\text { (3) }\end{array}$ & $\begin{array}{l}05 \text { September } \\
\text { (4) }\end{array}$ & & $\begin{array}{l}01 \text { October } \\
\text { (5) }\end{array}$ & $\begin{array}{l}24 \text { October } \\
\text { (6) }\end{array}$ & $\begin{array}{l}16 \text { November } \\
\text { (7) }\end{array}$ & Total & \\
\hline $\mathrm{N}_{0}$ & $1.10 \mathrm{a}^{\mathrm{b}}$ & & $1.91 \mathrm{a}$ & $0.95 \mathrm{~d}$ & $0.76 c$ & & $0.41 \mathrm{c}$ & $0.46 c$ & $0.41 \mathrm{c}$ & $5.9 c$ & $143 d$ \\
\hline $\mathrm{N}_{20}$ & $1.08 \mathrm{a}$ & & $1.96 a$ & $1.54 \mathrm{c}$ & $1.44 \mathrm{~b}$ & & $1.34 b$ & $1.54 \mathrm{~b}$ & $1.10 \mathrm{~b}$ & $10.0 \mathrm{~b}$ & $175 c$ \\
\hline $\mathrm{N}_{40}$ & $1.04 a$ & & $2.02 a$ & $2.10 \mathrm{a}$ & $2.08 \mathrm{a}$ & & $1.95 a$ & $1.97 a$ & $1.82 \mathrm{a}$ & $13.0 \mathrm{a}$ & $221 b$ \\
\hline $\mathrm{N}_{60}$ & $1.09 a$ & & $2.03 a$ & $2.14 a$ & $2.16 a$ & & $2.28 \mathrm{a}$ & $2.06 a$ & $2.05 a$ & $13.8 \mathrm{a}$ & $272 a$ \\
\hline $\mathrm{N}_{\mathrm{MB}}$ & $1.12 \mathrm{a}$ & & $1.97 a(0)^{c}$ & 1.97ab (38) & 1.96a (46) & & $2.05 a(47)$ & $1.81 \mathrm{ab}(43)$ & $1.80 \mathrm{a}(41)$ & $12.7 \mathrm{a}$ & $217 b$ \\
\hline $\mathrm{N}_{\text {soil }}$ & $1.05 a$ & & $2.07 a(0)$ & 1.91ab (20) & $2.02 \mathrm{a}(50)$ & & $2.20 \mathrm{a}(50)$ & $1.92 \mathrm{a}(50)$ & $1.95 a(50)$ & $13.1 \mathrm{a}$ & $228 b$ \\
\hline $\mathrm{N}_{\text {water }}$ & $1.16 a$ & & $1.98 \mathrm{a}(0)$ & $1.84 \mathrm{~b}(40)$ & $2.01 \mathrm{a}(47)$ & & $2.17 \mathrm{a}(40)$ & $1.94 a(39)$ & $1.92 \mathrm{a}(39)$ & $13.0 \mathrm{a}$ & $219 b$ \\
\hline \multicolumn{4}{|c|}{ Source of variation $\quad \mathrm{df}^{\mathrm{d}}$} & \multicolumn{7}{|c|}{ Mean squares } & \\
\hline \multirow{3}{*}{\multicolumn{2}{|c|}{$\begin{array}{l}\text { Treatment } \\
\text { Error } \\
\text { Significance }\end{array}$}} & 6 & 0.005 & 0.007 & 0.520 & 0.770 & 1.376 & 0.935 & 1.093 & 23.00 & 5038.10 \\
\hline & & 12 & 0.004 & 0.017 & 0.008 & 0.029 & 0.014 & 0.012 & 0.021 & 0.182 & 24.81 \\
\hline & & & ns & ns & & & & & & & \\
\hline \multicolumn{12}{|c|}{$\begin{array}{l}\text { a Number of growth cycles. } \\
\text { b Values followed by the same letter within a column are not significantly different. } \\
\text { c Values in brackets are fertiliser } \mathrm{N} \text { application rates }\left(\mathrm{kg} \mathrm{N} \mathrm{ha}^{-1} \mathrm{cycle}^{-1}\right) \text {. } \\
\text { d Degrees of freedom. } \\
\text { ns non-significant. } \\
{ }^{* *} \text { Significant at the } 0.01 \text { probability level. }\end{array}$} \\
\hline
\end{tabular}

and volatilisation to be negligible. Although there could be substantial $\mathrm{N}$ leaching at the beginning (due to rainfall and a shallow root system) and towards the end of the season (rainfall and a low canopy cover due to fewer tillers), in this study, for the purpose of calculating $\mathrm{N}$ application in this treatment, $\mathrm{N}$ leaching was assumed to be negligible, as the pasture was irrigated to field capacity in winter and in summer a soil deficit of about $15 \mathrm{~mm}$ was left after irrigation to provide a buffer for storing rainfall and minimising leaching.

$\mathrm{N}_{\text {up }}$ was estimated as the product of target forage yield and $\mathrm{N}$ content based on the $\mathrm{N}$ dilution curve of annual ryegrass as reported by Marino et al. (2004). Marino et al. (2004) established the critical plant $\mathrm{N}$ concentration $\left(\mathrm{N}_{\mathrm{C}}\right)$ for annual ryegrass as:

$\mathrm{N}_{\mathrm{C}}=4.08 \mathrm{DM}^{-0.38}$

where, $\mathrm{N}_{\mathrm{c}}$ is the critical total $\mathrm{N}$ concentration (\%) in forage that produces the maximum amount of biomass, dry matter (DM) forage yield is expressed in tha ${ }^{-1} ; 4.08$ is an empirical coefficient that represents the $N_{c}$ at 1 tha $^{-1}$; and -0.38 characterises the rate of reduction in $\mathrm{N}_{\mathrm{c}}$ during growth. The relationship is apparently independent of environmental conditions (Lemaire et al., 2008). An uptake of $62 \mathrm{~kg} \mathrm{~N} \mathrm{ha}^{-1}$ was estimated for a yield of $2.0 \mathrm{tha}^{-1}$, with critical $\mathrm{N}$ concentration of $3.1 \%$ using the $\mathrm{N}$ dilution curve (Marino et al., 2004).

$\mathrm{N}_{\text {init }}$ was the average of nitrate measurements from the WFDs (installed to a depth of $0.6 \mathrm{~m}$ ), which responded after irrigation or rainfall. The last irrigation of the previous growth cycle was used as initial soil $\mathrm{N}$ for the following growth cycle. The solution concentration in $\mathrm{mg} \mathrm{L}^{-1}$ was converted to $\mathrm{kg} \mathrm{N} \mathrm{ha}^{-1}$ using the volumetric soil water content $(\theta)$ of the active rooting depth of ryegrass $(D)$ with Eq. (3). This assumes that the resident nitrate concentration in the soil solution was well mixed and therefore equal to nitrate concentration in the mobile soil solution sampled by the detectors. This assumption may, however, not be completely accurate, but this provides a logical means to estimate available nitrate in soil when expensive and time consuming soil analyses are not available. Nitrate $\mathrm{N}$ is the dominant form of inorganic $\mathrm{N}$ in agricultural soils and $\mathrm{NH}_{4}-\mathrm{N}$ forms are usually excluded in soil testing (Vazquez et al., 2006), hence $\mathrm{NH}_{4}$ was assumed to be low and similar in all treatments.

$\mathrm{N}_{\text {init }}=\frac{0.226 \mathrm{WFD}_{\mathrm{NO}_{3}} \rho_{w} \theta D}{100}$

Table 6

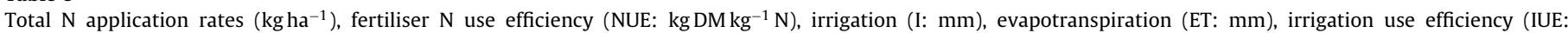

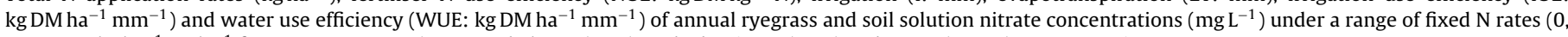
$20,40,60 \mathrm{~kg} \mathrm{ha}^{-1}$ cycle ${ }^{-1}$ for $\left.\mathrm{N}_{0}, \mathrm{~N}_{20}, \mathrm{~N}_{40}, \mathrm{~N}_{60}\right), \mathrm{N}$ mass balance $\left(\mathrm{N}_{\mathrm{MB}}\right)$, and adaptive $\mathrm{N}\left(\mathrm{N}_{\text {soil }}\right)$ and water $\left(\mathrm{N}_{\text {water }}\right)$ treatments in 2008.

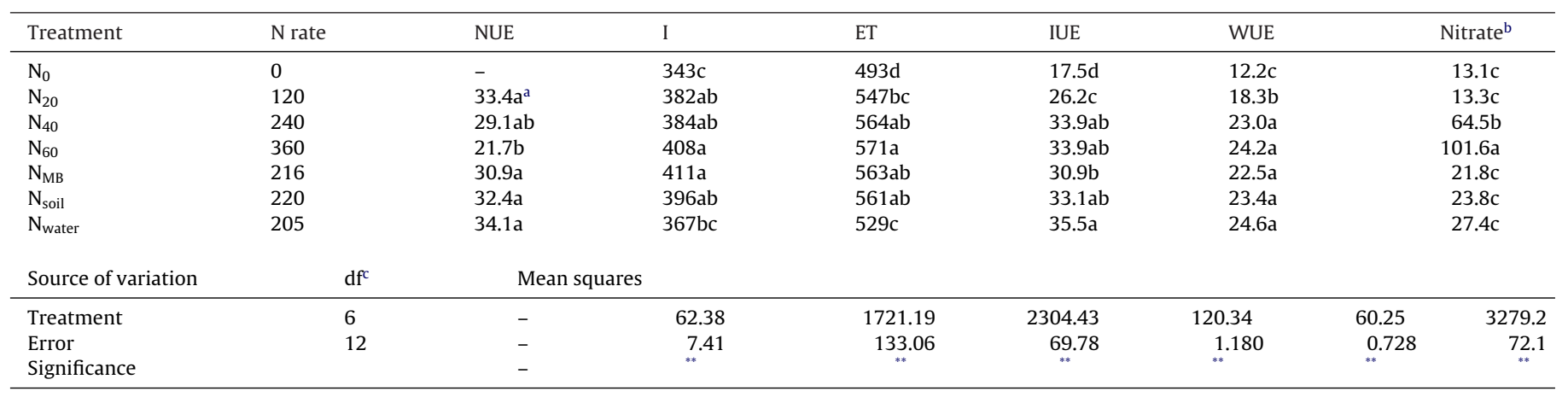

a Values followed by the same letter within a column are not significantly different.

b Mean nitrates collected from WFDs installed at $0.45 \mathrm{~m}$ soil depth.

c Degrees of freedom.

ns non-significant.

** Significant at the 0.01 probability level. 


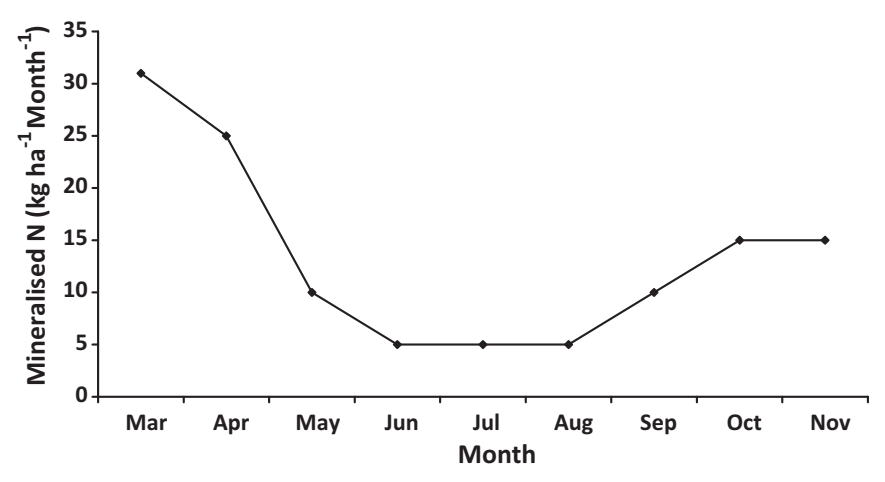

Fig. 1. Monthly $\mathrm{N}$ mineralisation estimates based on organic carbon collected at the beginning of the season.

where $\mathrm{N}_{\text {init }}$ is estimated initial $\mathrm{N}$ in $\mathrm{kg} \mathrm{ha}^{-1}$; $\mathrm{WFD}_{\mathrm{NO} 3}\left(\mathrm{mg} \mathrm{L}^{-1}\right)$ is average nitrate concentration measured from WFDs that recorded fronts just prior to harvest; $\mathrm{D}$ is the rooting depth $(0.6 \mathrm{~m}) ; \theta$ is water content at $3 \mathrm{kPa}$ suction $\left(0.41 \mathrm{~m}^{3} \mathrm{~m}^{-3}\right)$ when the sample is collected; $\rho_{\mathrm{w}}$ is the density of water $\left(1000 \mathrm{~kg} \mathrm{~m}^{-3}\right)$ and 0.226 is the factor for converting nitrate to nitrate- $\mathrm{N}$ and 100 is a conversion factor to $\mathrm{kg} \mathrm{ha}^{-1}$.

$\mathrm{N}_{\text {min }}$ was predicted from initial organic carbon from the soil samples collected at the beginning of the season (Fig. 1). Miles (2007) developed approximate $\mathrm{N}$ release curves for this study region based on soil organic carbon and long term weather data for soils with non-limiting $\mathrm{C}: \mathrm{N}$ ratios.

\subsubsection{Adaptive $N\left(N_{\text {soil }}\right)$}

In this treatment, mean soil solution nitrate concentration of $50 \mathrm{mg} \mathrm{l}^{-1}$ was selected as the optimum level by considering both yield and crop quality (Fig. 2). This value was between the nitrate concentration levels, which were detected by WFDs in the soil solution of the $\mathrm{N}_{30}$ and $\mathrm{N}_{60}$ treatments in 2007. This was a compromise between attaining maximum yield ( $\mathrm{N}_{60}$ treatment) and optimum quality $\left(\mathrm{N}_{30}\right)$. As a result, in $2008, \mathrm{~N}$ applied for the re-growth after harvest was based on average soil solution nitrate concentrations from all WFDs that responded to the last irrigation/rainfall event of the previous growth cycle. When average soil solution nitrate concentrations exceeded $50 \mathrm{mg} \mathrm{L}^{-1}$, no $\mathrm{N}$ was applied. When concentrations were below $25 \mathrm{mg} \mathrm{L}^{-1}$, the recommended $50 \mathrm{~kg} \mathrm{~N} \mathrm{ha}^{-1}$ was applied. In between these levels $\left(25-50 \mathrm{mg} \mathrm{L}^{-1}\right)$, half of the recommended rate $\left(25 \mathrm{~kg} \mathrm{~N} \mathrm{ha}^{-1}\right.$ ) was applied (Table 3$)$.

\subsubsection{Adaptive water $\left(N_{\text {water }}\right)$}

Results from 2007 showed that soil solution nitrate increased with higher inputs of fertiliser (Fig. 3a and b). We hypothesise that high $\mathrm{N}$ concentrations at 0.30 and $0.45 \mathrm{~m}$ depths increase the

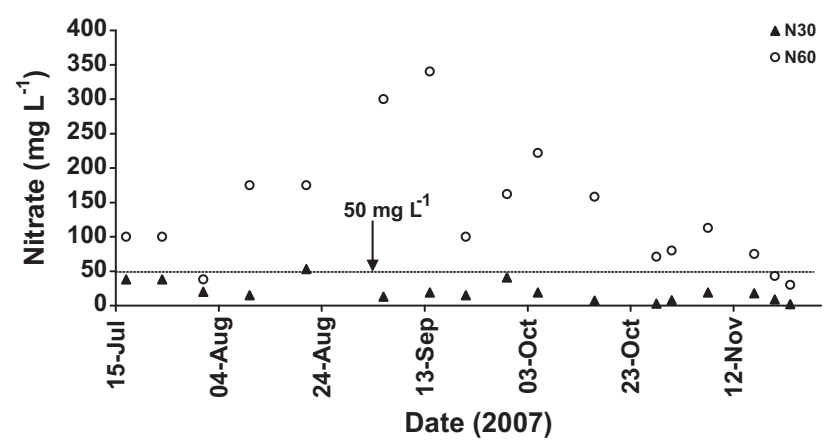

Fig. 2. Mean nitrate concentrations of wetting front detectors installed at all depths in treatments which received $30 \mathrm{~kg} \mathrm{Nha}^{-1}$ cycle $^{-1}\left(\mathrm{~N}_{30}\right)$ and $60 \mathrm{~kg} \mathrm{Nha}^{-1}$ cycle $^{-1}$ $\left(\mathrm{N}_{60}\right)$ in 2007 (dotted horizontal line represents nitrate threshold level).
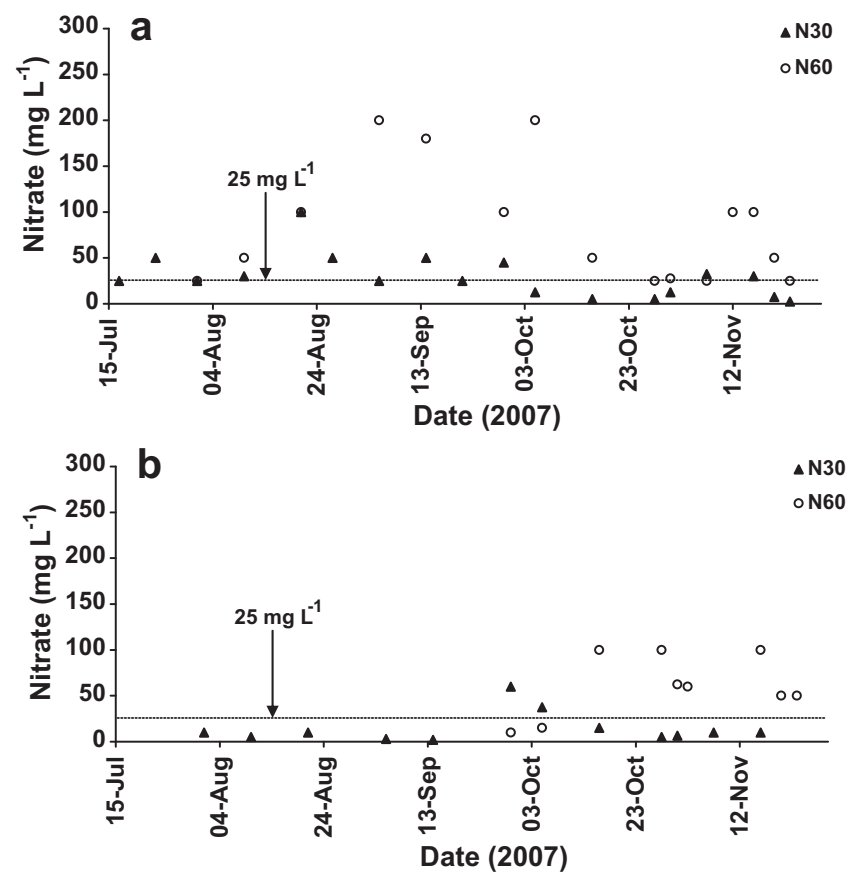

Fig. 3. Nitrate concentrations of wetting front detectors installed at (a) $0.30 \mathrm{~m}$ and (b) $0.45 \mathrm{~m}$ in treatments which received $30 \mathrm{~kg} \mathrm{Nha}^{-1} \mathrm{cycle}^{-1}\left(\mathrm{~N}_{30}\right)$ and $60 \mathrm{~kg} \mathrm{~N} \mathrm{ha}^{-1}$ cycle $^{-1}\left(\mathrm{~N}_{60}\right)$ in 2007 (dotted horizontal line represents nitrate threshold level).

probability of $\mathrm{N}$ leaching. This adaptive water treatment involved reducing irrigation in response to the depth that irrigation or rainfall penetrated, and to the nitrate concentration of the water sample (Table 3). Soil solution nitrate concentration of $25 \mathrm{mg} \mathrm{L}^{-1}$ (5.6 mg $\mathrm{NO}_{3}-\mathrm{N} \mathrm{L}^{-1}$ ) was taken as threshold. If concentrations collected from the $0.30 \mathrm{~m}$ deep WFD exceeded $25 \mathrm{mg} \mathrm{L}^{-1}$, the irrigation amount was reduced by watering only until the magnetically latched float of the $0.15 \mathrm{~m}$ WFD was activated (Fig. 3a). If the concentrations from the $0.45 \mathrm{~m}$ WFD exceeded $25 \mathrm{mg} \mathrm{L}^{-1}$, the scheduled irrigation event was cancelled (Fig. 3b).

Adaptive management is about designing and carrying out management actions as experiments from which one can learn. Therefore, the thresholds for the adaptive management treatments were somewhat arbitrarily selected in the knowledge that they would be improved with experience.

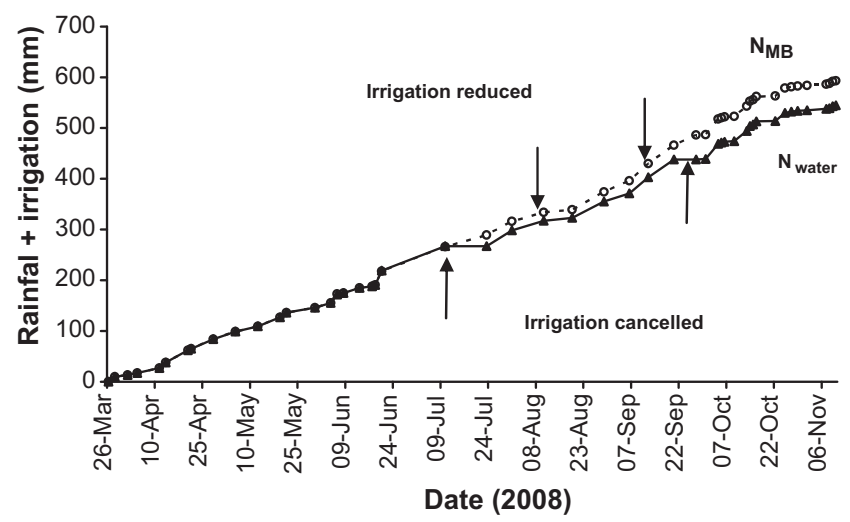

Fig. 4. Rainfall plus irrigation for $N$ mass balance $\left(N_{M B}\right)$ and adaptive water $\left(N_{\text {water }}\right)$ treatments in 2008. Upward arrows show cancellation of irrigation events and downward arrows reduced irrigation amount). 


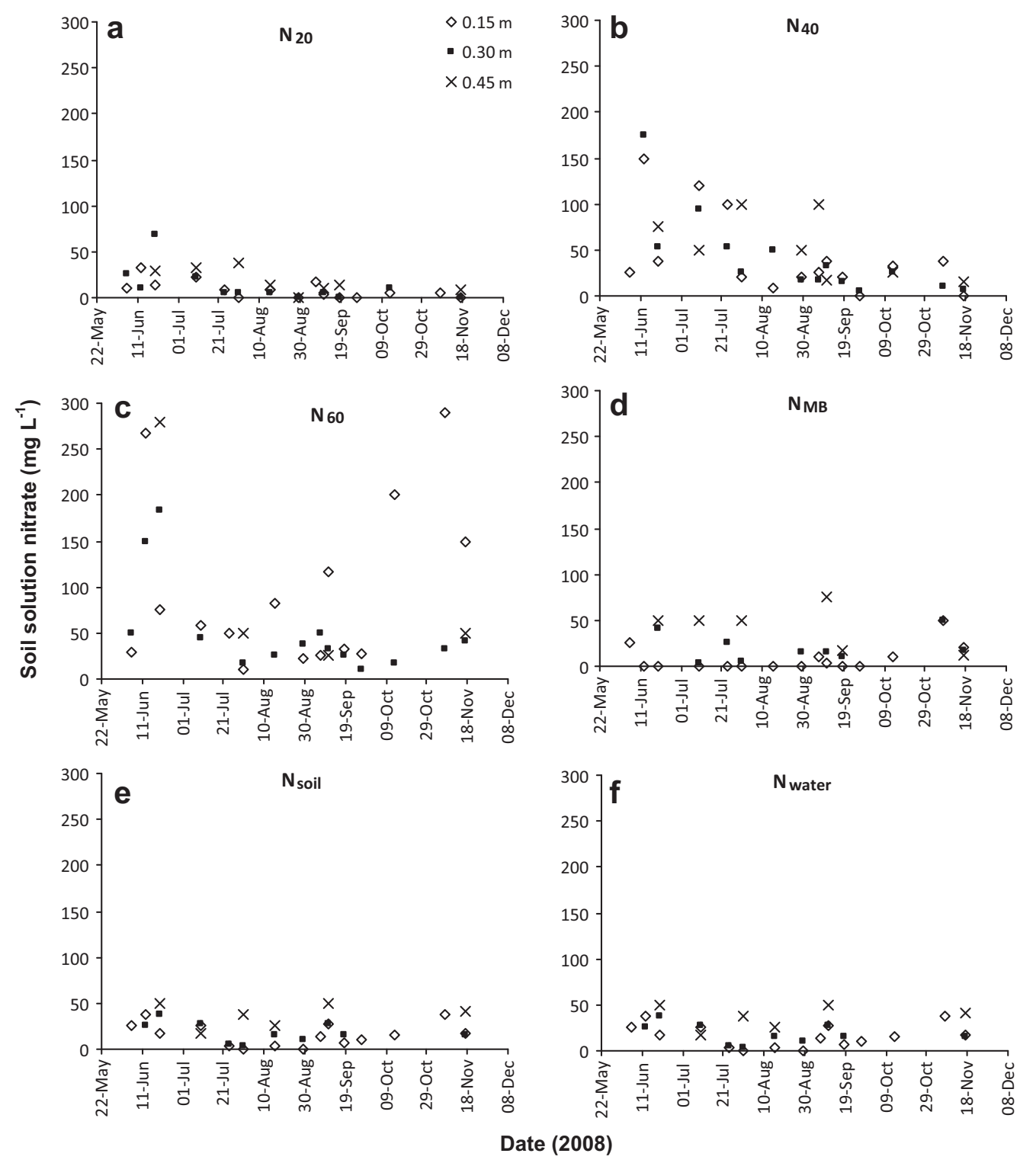

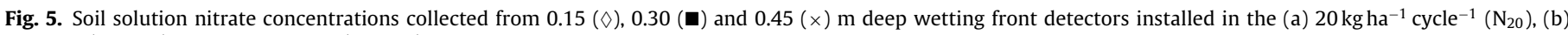
$40 \mathrm{~kg} \mathrm{ha}^{-1} \mathrm{cycle}^{-1}\left(\mathrm{~N}_{40}\right),(\mathrm{c}) 60 \mathrm{~kg} \mathrm{ha}^{-1}$ cycle $^{-1}\left(\mathrm{~N}_{60}\right),(\mathrm{d}) \mathrm{N}$ mass balance $\left(\mathrm{N}_{\mathrm{MB}}\right),(\mathrm{e})$ adaptive $\mathrm{N}\left(\mathrm{N}_{\text {soil }}\right)$ and (f) adaptive water $\left(\mathrm{N}_{\text {water }}\right)$ treatments in 2008.

\subsection{Data collection and calculations}

The pasture was harvested to $50 \mathrm{~mm}$ stubble height at the two to three leaf stage from $1 \mathrm{~m}^{2}$ quadrants using a manual grass mower. A total of nine samples per treatment (three from each plot) were collected for yield and quality determinations. After taking samples, the whole field was harvested to a height of $50 \mathrm{~mm}$ with a tractor drawn mower. Forage dry matter was determined by oven drying samples at $70^{\circ} \mathrm{C}$ to constant mass. Samples were milled to pass through a $0.1 \mathrm{~mm}$ sieve and were kept in bottles until quality could be determined. Total $\mathrm{N}$ was determined by Kjeldahl analysis (AOAC, 2000) and crude protein content (CP) was calculated by multiplying total $\mathrm{N}$ concentration by 6.25 .

Soil solution samples were collected from WFDs the day following an irrigation/rainfall event, in order to standardise the sampling time and to allow for some soil water redistribution within the profile. For each sample, nitrate concentration was analysed using an RQ Easy Nitrate Reflectometer (Merck KGaA, Germany). Soil cores were also sampled to a depth of $2 \mathrm{~m}$ in September and November 2008 from each plot using an auger. Nitrate was determined with an auto-analyzer after extraction using $1 \mathrm{M} \mathrm{KCl}$. Potential nitrate leaching (free draining) was determined as the difference in nitrate measurements below the root zone between two successive core sampling dates (September and November).

Crop water use or evapotranspiration of varying treatments was estimated using the soil water balance equation according to Jovanovic and Annandale (1999):

$\mathrm{ET}=P+I-R-\mathrm{Dr}-\Delta Q$

where $P$ is precipitation, $I$ is irrigation, $R$ is runoff, $D r$ is deep drainage below the rooting depth $(0.6 \mathrm{~m})$, and $\Delta Q$ represents soil water storage. All terms are expressed in $\mathrm{mm}$. $R$ was assumed to be negligible because of a dense pasture cover and relatively level field. Precipitation that exceeded soil water deficit to field capacity in the $0.6 \mathrm{~m}$ profile was considered to be lost as drainage. A positive $\Delta Q$ indicates a gain in soil water storage. $\Delta Q$ was estimated from soil water content measurements with a Diviner probe between two irrigation intervals to a depth of $0.6 \mathrm{~m}$. 


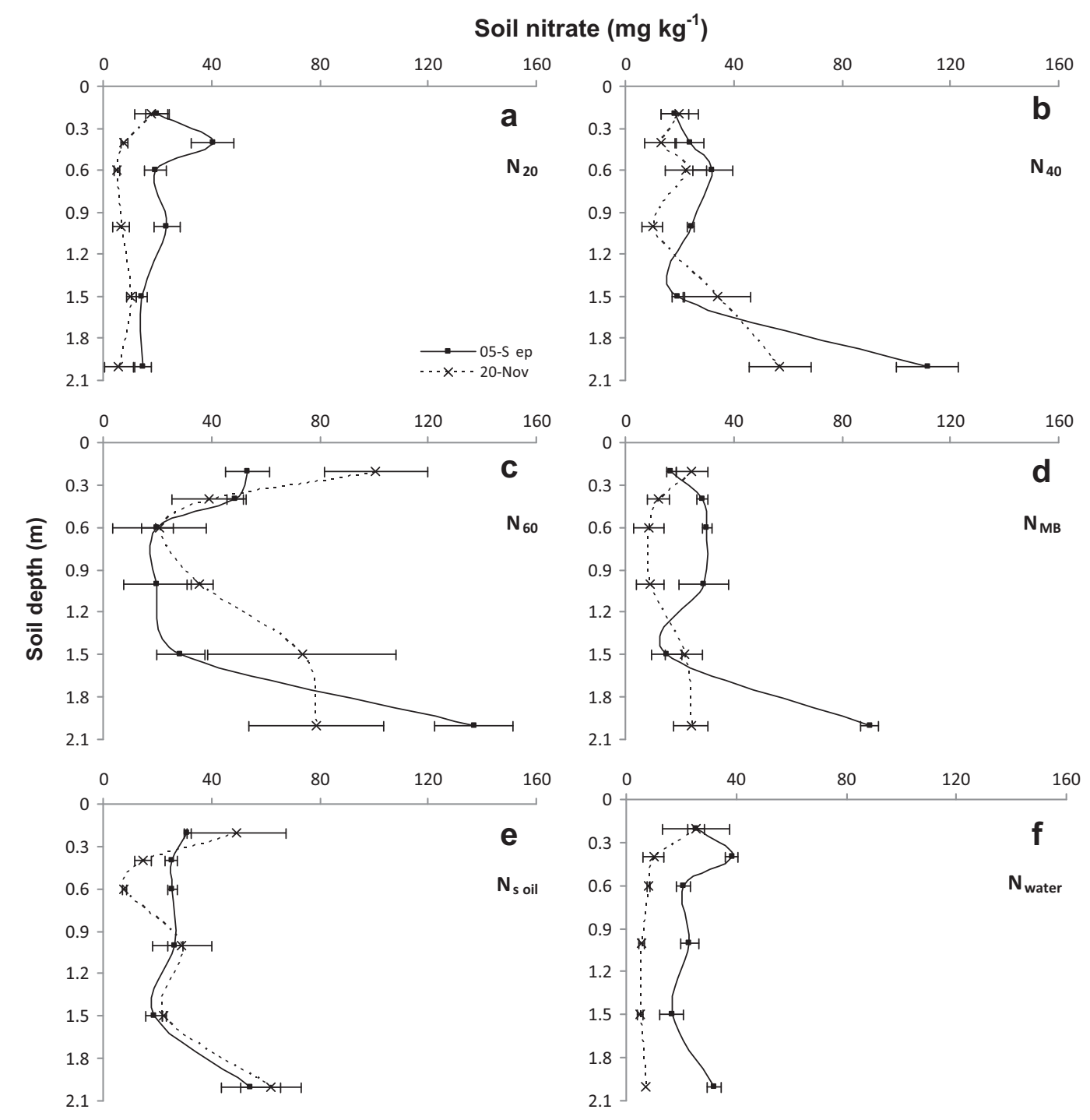

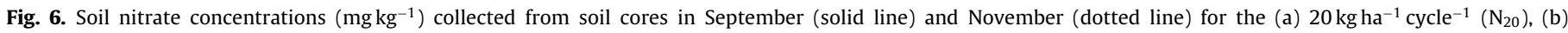
$40 \mathrm{~kg} \mathrm{ha}^{-1}$ cycle $^{-1}\left(\mathrm{~N}_{40}\right),(\mathrm{c}) 60 \mathrm{~kg} \mathrm{ha}^{-1}$ cycle $^{-1}\left(\mathrm{~N}_{60}\right),(\mathrm{d}) \mathrm{N}$ mass balance $\left(\mathrm{N}_{\mathrm{MB}}\right)$, (e) adaptive $\mathrm{N}\left(\mathrm{N}_{\text {soil }}\right)$ and (f) adaptive water $\left(\mathrm{N}_{\text {water }}\right)$ treatments in 2008.

Irrigation (IUE), water (WUE) and fertiliser N (NUE) use efficiencies were calculated using:

IUE $=\frac{\text { Forage yield }}{I}$

WUE $=\frac{\text { Forage yield }}{\text { ET }}$

NUE

$=\frac{\text { Forage yield from fertilised treatment }- \text { Forage yield from } \mathrm{N}_{0}}{\text { Applied } \mathrm{N}}$

\subsection{Statistical analysis}

Analyses of variance (ANOVA) for forage yield, crude protein, nitrogen use, irrigation applied, water use, irrigation and water use efficiencies, and soil solution nitrate concentrations were conducted using SAS (SAS, 2002). Multiple comparisons of means were performed using $\mathrm{LSD}_{\text {Tukey }}$ at a significance level of $P<0.05$.

\section{Results and discussion}

\subsection{Forage yield and quality}

In 2007, maximum forage yields were obtained with $\mathrm{N}_{60}$ while the optimum quality was for the $\mathrm{N}_{30}$ treatment (Table 4). In 2008, in all growth cycles, there were no significant forage yield differences between fixed $\mathrm{N}$ rates $\left(\mathrm{N}_{40}\right.$ and $\left.\mathrm{N}_{60}\right)$ and $\mathrm{N}_{\mathrm{MB}}, \mathrm{N}_{\text {soil }}$ and $\mathrm{N}_{\text {water }}$, except $\mathrm{N}_{\text {water }}$ in the third cycle (Table 5 ). In both years, there were no significant differences in forage yield between treatments in the first two growth cycles (Tables 4 and 5). As the seasons progressed, however, significantly different forage yields were exhibited showing the effect of $\mathrm{N}$ fertiliser, probably as a result of profile $\mathrm{N}$ depletion and reduced $\mathrm{N}$ mineralisation (Fig. 1). The significantly low forage yield of $\mathrm{N}_{\text {water }}$ in the third cycle of 2008 could be due to water stress as one irrigation event was cancelled. This did not occur in the fifth cycle when irrigation was skipped because of high rainfall (Table 1 ).

Forage crude protein (CP) concentrations above $220 \mathrm{~g} \mathrm{~kg}^{-1} \mathrm{DM}$ may drastically increase nitrate levels, leading to nitrate toxicity (Marais et al., 2003) and increases the risk of $\mathrm{N}$ losses from cows 
through urinary excretion (Tas et al., 2006). Crude protein concentrations exceeded this threshold in the $\mathrm{N}_{60}$ treatment $\left(272 \mathrm{~g} \mathrm{~kg}^{-1}\right.$ DM), while it was close to $220 \mathrm{~g} \mathrm{~kg}^{-1} \mathrm{DM}$ in the $\mathrm{N}_{\text {soil }}, \mathrm{N}_{\text {water }}, \mathrm{N}_{40}$, and $\mathrm{N}_{\mathrm{MB}}$ treatments (Table 5).

\section{2. $N$ rates and $N$ use efficiency}

Seasonal $\mathrm{N}$ fertiliser recommendation for annual ryegrass by the South African Department of Agriculture (SADA) is $350 \mathrm{~kg} \mathrm{~N} \mathrm{ha}^{-1}$ per year (usually $50 \mathrm{~kg} \mathrm{~N} \mathrm{ha}^{-1}$ per cycle) for a target forage yield of $12 \mathrm{tha}^{-1}$ year $^{-1}$. As there were no yield differences between $\mathrm{N}_{40}$ and $\mathrm{N}_{60}$, it was assumed that the recommended $50 \mathrm{~kg} \mathrm{~N}^{-1}$ per cycle would have produced a similar yield. Therefore, the recommended $\mathrm{N}$ rate of $50 \mathrm{~kg} \mathrm{Nha}^{-1}$ per cycle was used as the benchmark against which certain $\mathrm{N}$ treatments are compared. When all the parameters required in the $\mathrm{N}_{\mathrm{MB}}$ approach were measured or calculated, $\mathrm{N}$ application was reduced by $28 \%$, from a

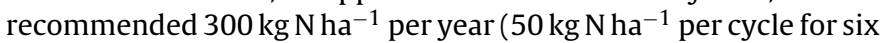
cycles) to only $216 \mathrm{~kg} \mathrm{~N} \mathrm{ha}^{-1}$ per year. However, the much simpler approaches of adjusting $\mathrm{N}$ or irrigation according to threshold values from a WFD reduced applications by $27 \%\left(220 \mathrm{~kg} \mathrm{~N} \mathrm{ha}^{-1}\right)$ and $32 \%\left(205 \mathrm{~kg} \mathrm{~N} \mathrm{ha}^{-1}\right)$ respectively, compared with the annual recommendation, with no significant impact on yield (Table 5). The most marked $\mathrm{N}$ fertiliser input reductions using adaptive management strategies were in the second growth cycle when reductions of $100 \%$ were observed for both adaptive $\mathrm{N}$ treatments with respect to SADA recommendations. In the 3rd cycle, reductions of $60 \%$ in $\mathrm{N}_{\text {soil }}$ and $23 \%$ in $\mathrm{N}_{\text {water }}$ were observed with respect to SADA recommendations (Table 6).

Generally, fertiliser use efficiencies (NUE) were higher in 2008 than 2007 (Tables 4 and 6), probably because no $\mathrm{N}$ was applied in the first growth cycle of 2008 . An additional growth cycle and higher forage yields obtained from the $\mathrm{N}_{0}$ treatment could also possibly explain reduced fertiliser NUE in 2007. In 2008, adaptive N and water managements showed significantly higher NUE compared to the fixed rate of $\mathrm{N}_{60}$.

\subsection{Water use efficiency}

In the $\mathrm{N}_{\text {water }}$ treatment in 2008, irrigations were cancelled on the 23rd of July in growth cycle three and the 27th of September in growth cycle five (Fig. 4). On both occasions, WFDs at $0.45 \mathrm{~m}$ had responded to rainfall. At the beginning of the fourth (August 10) and fifth (September 7) growth cycles, irrigations were reduced according to the $\mathrm{N}$ threshold trigger and the pasture was irrigated only until the $0.15 \mathrm{~m}$ deep WFDs responded.

There were significant differences in irrigation applied and water use between treatments in 2007 (Table 4) and 2008 (Table 6). In 2008 , significantly lower irrigation was applied to $\mathrm{N}_{\text {water }}$ than $\mathrm{N}_{\mathrm{MB}}$. This was due to reduced amount or cancellation of irrigation events as a result of deep WFD response. Seasonal irrigation use efficiency of $\mathrm{N}_{\text {water }}$ was significantly higher than that of $\mathrm{N}_{M B}$.

\subsection{Potential leaching}

Soil $\mathrm{NO}_{3}$ concentrations from WFDs (Fig. 5) and soil coring (Fig. 6) increased with increase in fertiliser application rate. The $\mathrm{N}_{\mathrm{MB}}$, adaptive $\mathrm{N}\left(\mathrm{N}_{\text {soil }}\right)$, and water $\left(\mathrm{N}_{\text {water }}\right)$ treatments showed similar soil solution nitrate concentrations, which were mostly lower than the South African (DWAF, 1993) permissible drinking water standard of $44.5 \mathrm{mg} \mathrm{NO}_{3} \mathrm{~L}^{-1}\left(10 \mathrm{mg} \mathrm{NO}_{3}-\mathrm{N} \mathrm{L}^{-1}\right)$ in all growth cycles except for the first (Fig. 5), where there was high initial inorganic $\mathrm{N}$ and mineralised organic $\mathrm{N}$ after tillage (Fig. 1). The soil solution collected from deep WFDs may not directly be considered to be leaching because the WFDs are not responsive to slow rates of drainage. However, the results do help to identify conditions when nitrate leaching is likely to occur, as shown by deep soil coring (Fig. 6).

Both adaptive $\mathrm{N}$ and water treatments showed relatively lower $\mathrm{NO}_{3}$ concentrations (soil solution and core samples) than treatment $\mathrm{N}_{40}$, even though the seasonal $\mathrm{N}$ application was similar. For example, mean $\mathrm{NO}_{3}$ concentrations collected from $0.45 \mathrm{~m}$ WFDs in the $\mathrm{N}_{40}$ treatment were significantly higher than those of the adaptive treatments (Table 6). Differences in soil nitrate at $2 \mathrm{~m}$ between the September (before the rainy season) and November (end of growing season) soil core sampling dates, were more than $50 \mathrm{mg} \mathrm{kg}^{-1}$ for the $\mathrm{N}_{40}$ and $\mathrm{N}_{60}$ fixed rate treatments (Fig. 6). The difference in nitrates in the adaptive treatments were, however, less than $25 \mathrm{mg} \mathrm{kg}^{-1}$ showing the advantages of adaptive $\mathrm{N}$ treatments in reducing the risk of $\mathrm{N}$ leaching.

\section{Conclusions}

Results from the first and second seasons showed that the optimum $\mathrm{N}$ application per cycle was between 30-60 and $40-60 \mathrm{~kg} \mathrm{~N} \mathrm{ha}^{-1}$ respectively, close to the current recommendation of $50 \mathrm{~kg} \mathrm{~N} \mathrm{ha}^{-1}$ per cycle. Seasonal $\mathrm{N}$ application could be reduced by $28 \%$ when many of the components of the $\mathrm{N}$ balance were measured at the start of each cutting cycle $\left(\mathrm{N}_{\mathrm{MB}}\right)$. However, the expense of such monitoring may not be justifiable on economic grounds. The trial showed that $\mathrm{N}$ savings from intensive monitoring could also be realised through a much simpler adaptive approach based on thresholds for the nitrate concentration in the soil solution. With respect to the baseline recommendations from the South African Department of Agriculture, $N$ application was reduced by $27 \%$ and $32 \%$ respectively in the two adaptive treatments (reduced $\mathrm{N}$ application and reduced water application). Both adaptive treatments resulted in an improvement of forage quality with no yield reduction, and a lower risk of $\mathrm{N}$ leaching.

The thresholds used in this study do have weaknesses in their interpretation. For example, the WFD used to collect water samples does not respond to fronts moving at suctions drier than $2-3 \mathrm{kPa}$ (Stirzaker, 2008). Furthermore, the nitrate concentration of the leaching water may be different from the resident soil water which would be available to the pasture (Corwin et al., 1991; van der Laan et al., 2010). Moreover, the thresholds were selected from just one season's data, but they could no doubt be improved.

Some may also argue that the use of simple thresholds is little more than an environmental management strategy (EMS), such as those promoted by the international standard organisation (ISO). However, farmers are intuitively adaptive managers and the use of simple monitoring and thresholds presents a way to structure their learning, and they represent our simplest conceptualisation of the problem to be managed (Wilson et al., 2009; Stirzaker et al., 2010). A good adaptive manager is expected to improve these thresholds as more experience is gained. A manager could for example select a lower threshold than $25 \mathrm{mg} \mathrm{L}^{-1}$, or alternatively he could combine the two adaptive treatments to seek alternative strategies.

\section{Acknowledgments}

We gratefully acknowledge the Water Research Commission (Project 1650 'Guidelines for irrigation management in pasture production' and Project 1574 'Adapting the Wetting Front Detector to the needs of small-scale furrow irrigators and providing a basis for the interpretation of salt and nutrient measurements from the water sample') and the National Research Foundation of South Africa for funding and the CSIR for providing scientific equipment, assistance and computer resources. 


\section{References}

AOAC, 2000. Official Methods of Analysis. Association of Official Analytical Chemists, Washington, DC

Andraski, T.W., Bundy, L.G., 2002. Using the pre-sidedress soil nitrate test and organic nitrogen crediting to improve corn nitrogen recommendations. Agron. J. 94, 1411-1418.

Asadi, M.E., Clemente, R.S., Gupta, A.D., Loof, R., Hansen, G.K., 2002. Impacts of fertigation via sprinkler irrigation on nitrate leaching and corn yield in an acid-sulphate soil in Thailand. Agric. Water Manage. 52, 197-213.

Collins, S.A., Allinson, D.W., 2004. Soil nitrate concentrations used to predict nitrogen sufficiency in relation to yield in perennial grasslands. Agron. J. 96, 1272-1281.

Corwin, D.L., Waggoner, B.L., Rhoades, J.D., 1991. A function model of solute transport that accounts for bypass flow. J. Environ. Qual. 20, 647-658.

DWAF, 1993. South African Water Quality Guidelines. Department of Water Affairs and Forestry, Pretoria, South Africa.

Eckard, R.J., Bartholomew, P.E.B., Tainton, N.M., 1995. The yield response of annual ryegrass Lolium multiflorum to varying nitrogen fertiliser application strategies. S. Afr. J. Plant Soil 23, 112-116.

Goulding, K., 2000. Nitrate leaching from arable and horticultural land. Soil Use Manage. 16, 145-151.

Hatfield, J.L., Prueger, J.H., 2004. Nitrogen over-use under-use and efficiency. In: Proceedings of the 4th International Crop Science Congress , 26 September-1 October 2004, Brisbane, Australia, http://www.cropscience.org.au/ icsc2004/plenary/2/140_hatfield.htm.

Holling, C.S., 1978. Adaptive Environmental Assessment and Management. John Wiley and Sons, New York.

Isermann, K., 1990. Share of agriculture in nitrogen and phosphorus emissions into surface waters of Western Europe against the background of their eutrophication. Nutr. Cycl. Agroecosys. 26, 253-269.

Jovanovic, N.Z., Annandale, J.G., 1999. An FAO crop factor modification to SWB makes inclusion of crops with limited data possible: examples for vegetable crops. Water SA 25, 181-190.

Lee, K.N., 1993. Compass and Gyroscope: Integrating Science and Politics in the Environment. Island Press, Washington, DC.

Lemaire, L., Jeuffroy, M., Gastal, F., 2008. Diagnosis tool for plant and crop N status in vegetative stage: theory and practices for crop $\mathrm{N}$ management. Eur. J. Agron. $28,614-624$.

Marais, J.P., Goodenough, D.C.W., de Figueiredo, M., Hopkins, C., 2003. The development of a Lolium multiflorum cultivar with a low moisture content and an increased readily digestible energy to protein ratio. Aust. J. Agric. Res. 54, 101-106.

Marino, M.A., Mazzanti, A., Assuero, S.G., Gastal, F., Echeverria, H.E., Andrade, F., 2004. Nitrogen dilution curves and nitrogen use efficiency during winter-spring growth of annual ryegrass. Agron. J. 96, 601-607.

Matson, P.A., Parton, W.J., Power, A.G., Swift, M.J., 1997. Agricultural intensification and ecosystem properties. Science 277, 504-509.

Miles, N., 2007. Nitrogen fertilisation: when to count on soil organic matter. Farmer's weekly $92,23-44$.
Peyraud, J.L., Astigarraga, L., 1998. Review of the effect of nitrogen fertilisation on the chemical composition, intake, digestion and nutritive value of fresh herbage: consequences on animal nutrition and $\mathrm{N}$ balance. Anim. Feed Sci. Technol. 72, 235-259.

Samanasena, H.A., Horne, D.J., Scotter, D.R., Kemp, P.D., 2004. The effects of irrigation scheduling on nitrogen and phosphorous leaching under pasture. Trop. Agric. Res. 16, 193-203.

SAS, 2002. Statistical Analysis Software, Version 9.01. SAS Institute, Cary, NC, USA.

Smil, V., 1999. Nitrogen in crop production: an account for global flows. Global Biogeochem. Cycl. 13, 647-662.

Soil Classification Working Group, 1991. Soil Classification: A Taxonomic System for South Africa. No 15. Department of Agricultural Development, Pretoria, South Africa.

Steffen, W., Crutzen, P.J., McNeill, J.R., 2007. The Anthropocene: are humans now overwhelming the great forces of nature? Ambio 36, 614-621.

Stirzaker, R.J., 1999. The problem of irrigated horticulture: matching the biophysical efficiency with the economic efficiency. Agroforest. Syst. 45, 187-202.

Stirzaker, R.J., 2003. When to turn the water off: scheduling micro-irrigation with a wetting front detector. Irrigation Sci. 22, 177-185.

Stirzaker, R.J., 2008. Factors affecting sensitivity of wetting front detectors. Acta Hort. 792, 647-653.

Stirzaker, R.J., Hutchinson, P.A., 2005. Irrigation controlled by a Wetting Front Detector: field evaluation under sprinkler irrigation. Aust. J. Soil Sci. Res. 43, 935-943.

Stirzaker, R.J., Biggs, H.C., Roux, D.J., Cilliers, P., 2010. Requisite simplicities to help negotiate complex environmental problems. Ambio 39, 600-607.

Tamminga, S., 1992. Nutrition management of dairy cows as a contribution to pollution control. J. Dairy Sci. 75, 345-357.

Tas, B.M., Taweel, H.Z., Smit, H.J., Elgersma, A., Dijkstra, J., Tamminga, S., 2006. Utilisation of $\mathrm{N}$ in perennial ryegrass cultivars by stall-fed lactating dairy cows. Livestock Sci. 100, 159-168.

Tesfamariam, E.T., Annandale, J.G., Steyn, J.M., Stirzaker, R.J., 2009. Exporting large volumes of municipal sludge through turfgrass sod production. J. Environ. Qual. 38, 1320-1328.

Tilman, D., Cassman, K.G., Matson, P.A., Naylor, R., Polansky, S., 2002. Agricultural sustainability and intensive production practices. Nature 418, 671-677.

van der Laan, M., Stirzaker, R.J., Annandale, J.G., Bristow, K.L., du Preez, C.C., 2010. Monitoring and modelling draining and resident soil water nitrate concentrations to estimate leaching losses. Agric. Water Manage. 97, 1779-1786.

Vazquez, N., Pardo, A., Suso, M.L., Quemada, M., 2006. Drainage and nitrate leaching under processing tomato with drip irrigation and plastic mulching. Agric. Ecosyst. Environ. 112, 313-323.

Walters, C., 1986. Adaptive Management of Renewable Resources. MacMillan Publishing Company, New York.

Wilson, G., Edwards, M., Curruthers, G., 2009. Environmental management systems as adaptive natural resource management: case studies from agriculture. In: Allan, Catherine, A., Henry, S.G. (Eds.), Adaptive Environmental Management: A Practitioner's Guide. Springer, p. 351. 